\title{
Euglenophytes reported from karst sink-holes in the Malopolska Upland (Poland, Central Europe)
}

\author{
K. Wołowski \\ Polish Academy of Sciences, W. Szafer Institute of Botany, Department of Phycology, ul. Lubicz 46, PL 31-512 Kraków, Poland. \\ E-mail: wolowski@ib-pan.krakow.pl
}

\begin{abstract}
In karst sink-holes within the environs of Czajków, and in an old fishpond within the Skorocice gypsum valley, 24 taxa of euglenophytes, comprising Euglena (10), Phacus (9), Lepocinclis (2), and Trachelomonas (3) were found. Four of them, Phacus elegans Pochmann, Ph. arnoldii Swirenko var. ovatus Popova, Ph. plicatus Conrad, and Ph. curvicauda Swir. var. robusta Allorge \& Lefèvre, are new for the Polish flora, and rarely reported worldwide.
\end{abstract}

Keywords : Euglenophyta, Central Europe, Poland, Malopolska Upland, karst sink-holes, fishponds.

\section{Introduction}

The investigated area lies in the eastern part of the Nida Basin, a wide depression within the Ś wiẹtokrzyskie Mountains and Cracow-Częstochowa Upland. The origin of the karst sink-holes in this area is connected to the occurrence of varying ground water levels. The highest level lies just below the surface of Quaternary formation and the lowest is situated in the Tertiary gypsum bed on the impermeable Palaeozoic substratum. The water dissolves the gypsum group which, in turn, leads to the creation of empty spaces. The karst sink-holes, occupying the territory situated in the wide depression, belong to Staszów environs. There are several small sink-holes situated in a field (Ochyra 1985) at the village of Czajków. The Biosphere Reserve in the Skorocice gypsum valley contains several karstic sink-holes and two old unexplored fishponds and is, from a geological point of view, very similar to the Malopolska Upland.

Apart from Charophyceae studied by Karczmarz et al. (1976), no other phycological studies have been carried out in this area. Paleobotanical studies on the sediments filling the sink-holes have been done by Szczepanek $(1968,1971)$, and valuable information about vascular plants of this region has been given by Ochyra $(1979,1985)$. The Bryophytes of the region have also been described by Kuc $(1959,1964)$, Ochyra (1981), Ochyra \& Szmajda (1978), and Karczmarz \& Szczepanek (1984).

\section{Material and methods}

One collection of material was made from each location during summer (June 1986). Unfiltered water (containing plankton) along with the bottom of two sink-holes at Czajków and two fishponds at Skorocice were sampled. The water temperature in the sink-holes at Czajków was $17^{\circ} \mathrm{C}$ and the $\mathrm{pH}$ value was 5.4 (area ca. $=0.80$ ha, depth $=40 \mathrm{~cm})$. Similar features were exhibited by the Skorocice fishponds (area about 1 ha, depth $=50 \mathrm{~cm})$, which showed a temperature of $22.5^{\circ} \mathrm{C}$ and a $\mathrm{pH}$ of 6.2 . The samples were placed in $25 \mathrm{ml}$ plastic bottles and stored in the refrigerator at $15^{\circ} \mathrm{C}$. Observations were carried out on the living material, using Carl Zeiss Jena and Nikon - Eclips 600 light microscopes. In order to mobilize the cells immediately before microscope study, $0.5 \%$ glutaraldehyde was sometimes used. The quantity of cells on the slides was evaluated as follows: $1=$ single, $2=$ very rare, $3=$ rare, $4=$ moderately numerous, $5=$ numerous, $6=$ very numerous.

\section{Results}

The general taxonomic system followed here agrees with Leedale (1967). For the genus Euglena, taxonomic descriptions were arranged according to Pringsheim (1956); for the genus Phacus; according to Pochmann (1942) and Popova \& Safonova (1976), and for the genus Trachelomonas, according to Deflandre 
(1926). Taxa rarely reported worldwide and new to the Polish flora are indicated with an asterisk (*).

\section{Genera Euglena}

\section{Subgenus Rigidae Pringsheim 1956}

Euglena acus Ehrenberg 1830 (=Euglena acus var. rigida Hübner, var. lata Svirenko, var. longissima Deflandre, E. acutissima Lemmermann). Figs 1-5, 58. Cells 15-28 $\mu \mathrm{m}$ wide, 60-137 $\mu \mathrm{m}$ long, needle-shaped, elongate spindle-shaped, sometimes bent and sometimes assuming an S-shape; anterior end narrowed and apically truncated; posterior end tapered to a long hyaline incision which can be bent at $90^{\circ}$ angle (Fig. 5). Moderately numerous specimens were found in a pond at Skorocice. Cosmopolitan, widespread; occurs in ditches, ponds, small flowing rivers, fish and village ponds and swamps, as well as in acid ponds and brackish-water; indicator of mild to moderately polluted water. Note: among found specimens of E. acus, one

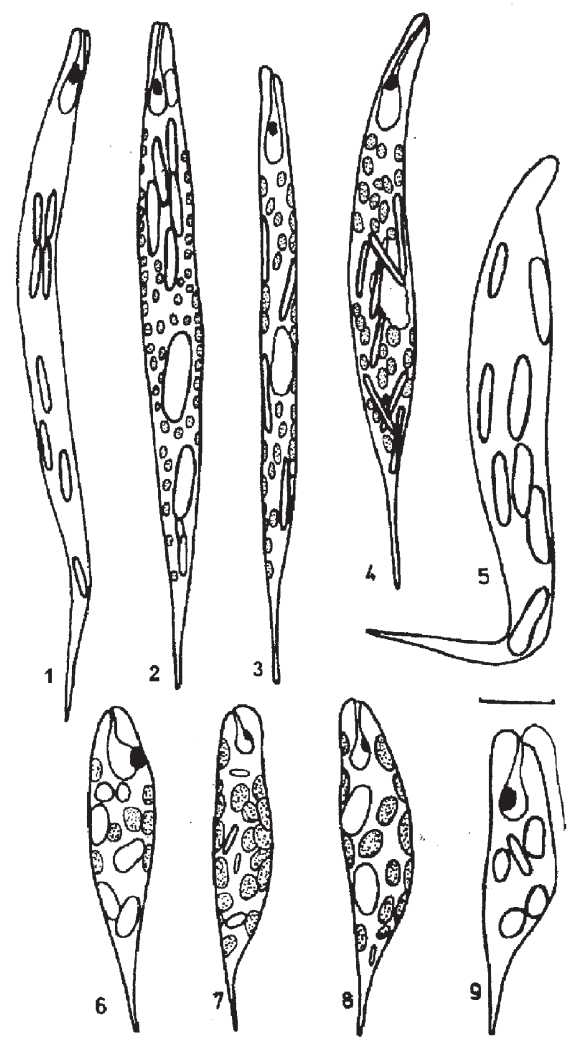

Figs 1-9. 1-5. Euglena acus; 6-9. E. limnophila var. swirencoi. Scale bar $=10 \mu \mathrm{m}$. specimen (Fig. 5) was similar to Euglena incurva Matvienco (1938) exhibiting dimensions smaller than those reported in the original Matvienko (1938) description: $15 \mu \mathrm{m}$ wide, $204 \mu \mathrm{m}$ long with several paramylon grains.

Euglena tripteris (Dujardin) G.A. Klebs 1883 (=Euglena tora A. Stokes, Phacus tripteris Dujardin Figs 10-13, 65. Cells 18-19 um wide, 94-103 um long, flattened, ribbon-shaped, spirally twisted and triangular in cross section, bowed inwards and giving the appearance of 3 ridges; anterior end slightly narrowed, sometimes slightly truncate; posterior end tapering to a long tail-piece, slightly spirally twisted. Rare specimens were found among filamentous of Spirogyra weberii and Oscillatoria sp. in a pond at Skorocice. Cosmopolitan; widespread; occurs in peat bogs, ponds, pools, ditches and lakes; planktonic or associated with surfaces; usually scarce; known to range from unpolluted to moderately polluted water; $\beta-\alpha$ mezosaprobic. te: described specimens (Figs 10, 12) with paramylon grains larger and more numerous than those originally reported by Klebs 1883 (two large paramylon grains).

Euglena limnophila Lemmermann var. swirenkoi (Arnoldi) T.G. Popova 1955 (= Euglena swirenkoi Arnoldi, E. limnophila var. minor Dreżepolski 1925). Figs 69. Cells 8-12 $\mu \mathrm{m}$ wide, 40-48 $\mu \mathrm{m}$ long, spindle-shaped or broadly spindle-shaped, sometimes bent; anterior end apically truncate; posterior end tapering to a sharp tail-piece, usually curved; pellicle slightly striated. Chloroplasts numerous, small disc-shaped, without pyrenoids; paramylon bodies ring-like or rod-shaped, several; flagellum shorter than cell length; eyespot small, located towards the end of canal. Rare specimens were found with filaments of Spirogyra weberii in a pond at Skorocice. Common, reported from Europe and Asia; occurs in ponds, rivers, sewage ditches; indicator of moderately polluted water.

Euglena spirogyra Ehrenberg 1838. Figs 59-62.

(= E. spirogyra $\beta$-fusca Klebs, Euglena fusca (Klebs) Lemm., E. spirogyra var. abrupto-acuminata Lemm., E. spirogyra var. lacticlavius Hübner, E. spirogyra var. marchica Lemm). Cells 12-15 $\mu \mathrm{m}$ broad, 95-107 $\mu \mathrm{m}$ long, longitudinally spindle-shaped; anterior end bluntly rounded, posterior end extended into a distinctly bent tail-piece. Rare specimens were found among filaments of Spirogyra weberii in a pond at Skorocice.

Cosmopolitan, widespread; occurs in different water bodies, taxa exhibits affinity to wastewater, reported as saprophilous (Wołowski 1998). Note: earlier reports from Poland of varieties fusca and lacticlavius, Wo- 


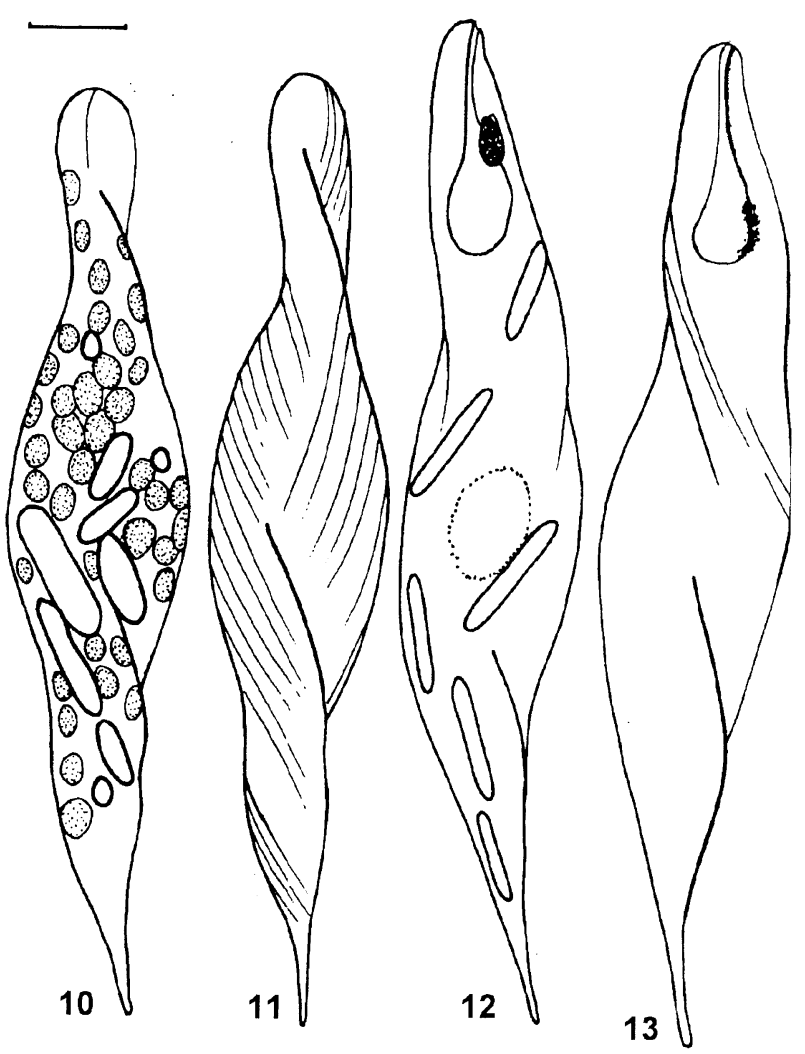

Figs 10-13. Euglena tripteris, morphology details of cells. Scale bar $=10 \mu \mathrm{m}$.

lowski (1998), should be treated as synonyms of $E$. spirogyra.

\section{Subgenus Lentiferae Pringsheim 1956}

Euglena proxima Dangeard (after Pringsheim 1956) Fig. 26. Cells 14-17.5 um wide, 83-85 $\mu \mathrm{m}$ long, longitudinal fusiform, anterior end rounded; tapering and passing into sharp tail-piece at the posterior end; pellicle spirally striated. Chloroplasts numerous, without pyrenoids; paramylon grains small. Very rare specimens were among filaments of Spirogyra weberii found in a pond at Skorocice.

Cosmopolitan, common, widespread; occurs in small water bodies, sometimes form neuston membranes, also in salt water, saprophilous (Wołowski 1998). Note: similar to E. spathirhyncha Skuja.

\section{Subgenus Catilliferae Pringsheim 1956}

Euglena agilis H.J.Carter 1856 (= Euglena pisciformis G.A.Klebs, E. nana L.P. Johnson, E. pisciformis var. fallax E.G. Pringsheim, lata E.G. Pringsheim, mucronata E.G. Pringsheim, obtusa E.G. Pringsheim, procera E.G. Pringsheim, striata E.G. Pringsheim, Euglena agilis var. pyrenoidea J. Schiller, circumsulcata J. Schiller, praexicisa J. Schiller, varians J. Schiller). Figs 19-20. Cells 11-15 $\mu \mathrm{m}$ wide, 27-41 $\mu \mathrm{m}$ long, when fully extended nearly oval, broadly ovoid; anterior end bluntly rounded, posterior end coming to a short, rather blunt point. Numerous specimens were found in a pond at Skorocice. Cosmopolitan, widespread; in permanent and temporary bodies of water including ditches, puddles, ponds, lakes and peat bogs, sometimes associated with sand; an indicator of mode- 


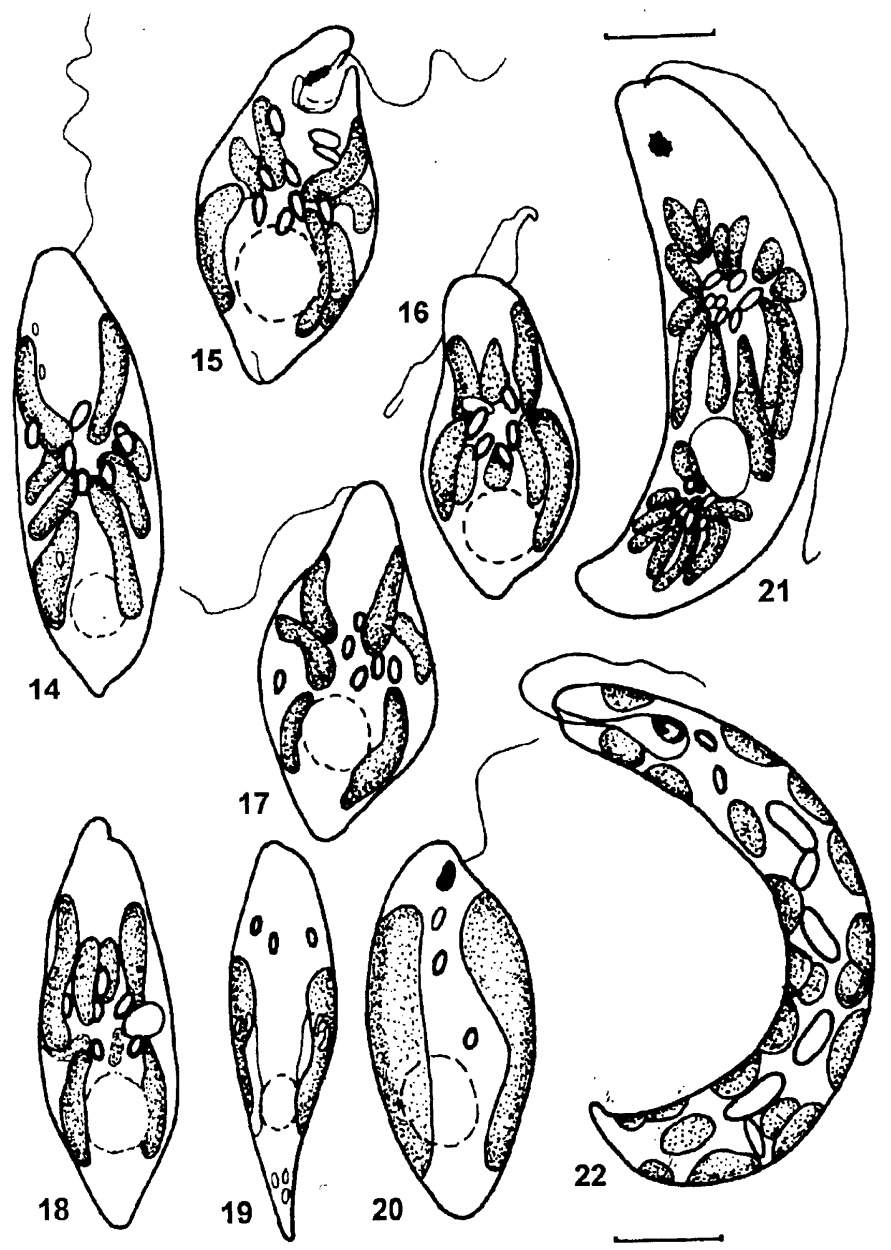

Figs 14-22. 14-18. Euglena viridis; 19-20. E. agilis; 21. E. geniculata; 22. E. deses. Scale bar $=10 \mu \mathrm{m}$.

rately polluted water. Note: cells have very variable shapes (Zakry's 1997, Wołowski 1998, 2002).

Euglena caudata $\mathrm{K}$. Hübner1886 (= Euglena caudata var. minor Deflandre). Figs 24-25. Cells 25-28 $\mu \mathrm{m}$ wide, 64-95 um long, spindle-shaped or broadly spindleshaped; anterior end slightly extended and apex truncate; posterior end tapering to a hyaline tail-piece. Moderately numerous specimens were found among filamentous of Spirogyra veberii in a pond at Skorocice. Cosmopolitan; widespread, occurred in lakes, ponds, puddles, ditches, rice-fields and slow-flowing rivers; ranges from unpolluted to heavily polluted water.

\section{Subgenus Radiatae Pringsheim 1956}

Euglena viridis Ehrenberg 1830 (=Enchelys tertia Hil.; Enchelys viridis E. Schrank, Cercaria viridis, O.F. Müller; Raphanella urbica Bory). Figs 14-18, 23, 63.

Cells 12-18 $\mu \mathrm{m}$ wide, 38-40 $\mu \mathrm{m}$ long, spindle-shaped to broadly spindle-shaped; anterior end rounded; posterior end usually tapering to a point of variable length. Very numerous specimens found in ponds at Skorocice and in a karst sink-hole (I) at Czajków. Cosmopolitan, widespread; very tolerant for different types of wastewater. Note: Some specimens had dispersed chloroplast (Figs 17, 18). 
Euglena geniculata (F. Schmitz) Dujardin 1841 (=Euglena schmitzii Gojdics et Zakry's 1986). Fig. 21. Cells 12.5-15.0 $\mu \mathrm{m}$ wide, 50-85 $\mu \mathrm{m}$ long, nearly cylindrical to bluntly spindle-shaped; anterior end rounded, posterior end narrowing to a sharp tail-piece. Rare specimens found with filaments of Spirogyra weberii and Oscillatoria sp. in a pond at Skorocice. Cosmopolitan, widespread occurred in ponds, ditches and puddles, on muddy banks; known from very pure to heavily polluted water, including water very rich in organic matter and sewage (Wolowski 2002).

\section{Subgenus Serpentes Pringsheim 1956}

Euglena deses Ehrenberg fo. intermedia (Lemmermann) T.G. Popova 1966 (= Euglena intermedia (Klebs) Schmitz) Figs 22, 64. Cells 8-15 $\mu$ m wide, 77$100 \mu \mathrm{m}$ long, cylindrical; anterior end slightly narrowed, rounded at apex; posterior end narrowing to a short, rounded tail-piece. Numerous specimens were found among filaments of Spirogyra weberii and Oscillatoria sp. in a pond at Skorocice. Cosmopolitan; widespread, in ponds, puddles, peat bogs and rice fields, tolerant of saline water; considered an indicator of moderately polluted water.

\section{Genus Lepocinclis}

Lepocinclis ovum (Ehrenberg) Lemmermann 1901 (= Euglena ovum Ehrenberg, Chloropeltis ovum F. Stein, Phacus ovum (Ehrenberg) G. A. Klebs). Figs 31-32. Cells 16-22 $\mu \mathrm{m}$ wide, 36-38 $\mu \mathrm{m}$ long, broadly ovate; anterior end rounded, posterior end with a blunt tail-piece. Rare specimens were found among mats of filamentous algae in a pond at Skorocice. Cosmopolitan; widespread, occurs in ditches, swamps and small ponds as well as in the shallow water of bays and lagoons, also in brackish-waters; indicator of moderately polluted water.

Lepocinclis ovum (Ehrenberg) Lemmermann 1901 var. dimidio-minor (=Euglena ovum Ehrenberg, Chloropeltis ovum F. Stein, Phacus ovum (Ehrenberg) G. A. Klebs). Figs 27-30, 66, 68. Cells 14-15 $\mu \mathrm{m}$ wide, 18$24 \mu \mathrm{m}$ long, broadly ovate; anterior end rounded, posterior end with a short blunt tail-piece; pellicle with striation in a left-hand spiral. Very rare specimens were found among mats of Spirogyra weberii in a pond at Skorocice. Not common, rare, reported from Europe, Asia, North America and Africa; occurs in small, stagnant water bodies.

\section{Genus Phacus}

\section{Sectio Phacus Pochmann 1942}

Phacus acuminatus A. Stokes (after Popova \& Safonova 1976). Fig. 36. Cells 22-23 $\mu \mathrm{m}$ wide, 25-30 $\mu \mathrm{m}$ long, broadly ovoid to oval in outline, anterior narrowly rounded and shallowly bilobed, posterior end broadly rounded with short blunt cauda. Rare specimens were found at the bottom of karst sink-holes (I, II). Cosmopolitan, wide spread; occurs in swamps, ditches, puddles, ponds, fish ponds and lakes, often in the same habitats as Euglena or Lepocinclis; known from very clean water through to moderately polluted water (Wolowski 2002). Note: is a highly variable species with a variety of cell shapes, and varying number of paramylon grains at the posterior end. Popova (1951) reported three varieties. Pochmann (1942) set aside nine subspecies which Huber-Pestalozzi (1955) changed into varieties with a key to the identification. Species very similar to Ph. brevicaudatus Lemmmermann.

\section{*Phacus plicatus Conrad 1943. Figs 33-35.}

Cells 15-16 $\mu \mathrm{m}$ wide, ca. $29 \mu \mathrm{m}$ long, flattened, leafleted, bent, anterior end slightly narrowing and shallowly bilobed with one side projecting more than the other; gradually narrowing to small blunt extension at the posterior end; periplast slightly longitudinally striated; chloroplasts small, plate shaped; stigma small two large paramylon grains, and several small ones placed at the sides of the cell. Very rare specimens were found in a sink-hole (II) at Czajków. Rare, reported from Europe: Belgium, Ukraine, and South America: Argentina in small water bodies. Note: found specimens were broader than the type described by Conrad 1934 (see p. 3: 8-10 $\mu \mathrm{m}$ wide). Similar to Ph. raciborskii Drezepolski 1925, but the last one is wedgeshaped and folded along longitudinal axis. Also similar to Ph. inflexus Pochmann 1942 which is S-twisted with two sides projected and bilobed at the anterior end. Specimen reported by Tell and Confortii (1986) from Argentina as $P h$. plicatus remaninsent of $P h$. raciborskii.

Phacus orbicularis K. Hübner 1886 fo. communis Popova 1947. Figs 39-40. Cells 35-36 um wide, 48-50 $\mu \mathrm{m}$ long, orbicular to broad ovoid in outline; anterior end slightly narrowly rounded; posterior end broadly rounded with a short curved tail-piece; apical groove nearly full length of cell. Rare specimens were found at the bottom of sink-holes (I, II) at Czajków. Cosmopolitan, widespread; occurs in stagnant, mineralised, polluted and humus waters, in ponds, swamps, ditches 

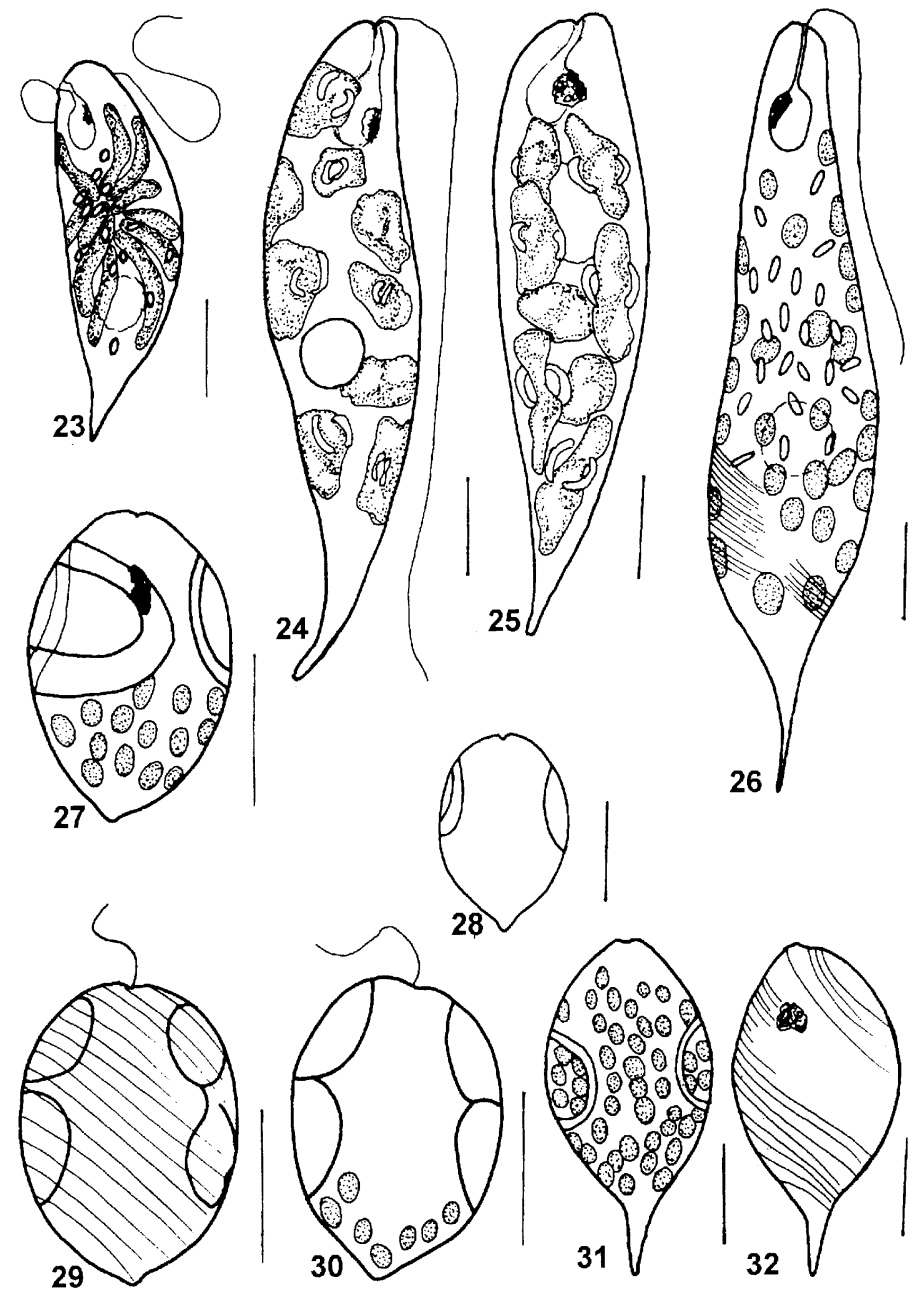

Figs 23-32. 23. Euglena viridis; 24-25. E. caudata; 26. E. proxima; 27-30. Lepocinclis ovum var. dimidio-minor; 31-32. L. ovum. Scale bar $=10 \mu \mathrm{m}$.

and lakes, also in saltwater; indicator of clean to mildly polluted water (Wolowski 2002).

Phacus brachykentron Pochmann 1942. Fig 37. Cells ca. $30 \mu \mathrm{m}$ wide, 37-38 $\mu \mathrm{m}$ long, broadly ovoid; anterior end rounded; apical furrow up to half of cell length; posterior end broadly rounded with a short (ca. 3 $\mu \mathrm{m}$ long ) tail piece turning to the left side. Rare specimens were found in sink-holes (I, II) at Czajków. Not common, reported from Europe: Czech Republic, Germany, Hungary, Poland and Slovakia; North America: USA, Central America: Panama; South America: Ar- gentina, Africa: Chad; occurs in: ponds. Note: found specimens were larger than those described by Pochmann (1942), dimensions closer to specimens reported by Tell and Conforti (1986, see p. 79: 24-36 $\mu \mathrm{m}$ long, 15-26 $\mu \mathrm{m}$ wide) from Argentina, and to specimens reported by Yamagishi (1992, see p. 38, pl. 13, Figs 4-5) from Taiwan.

* Phacus arnoldii Swirenko var. ovatus Popova 1947 (=Phacus arnoldii Swir. In Skuja 1932, Ph. warszawiczii Dreżepolski 1925). Figs 41-46, 71-72. 

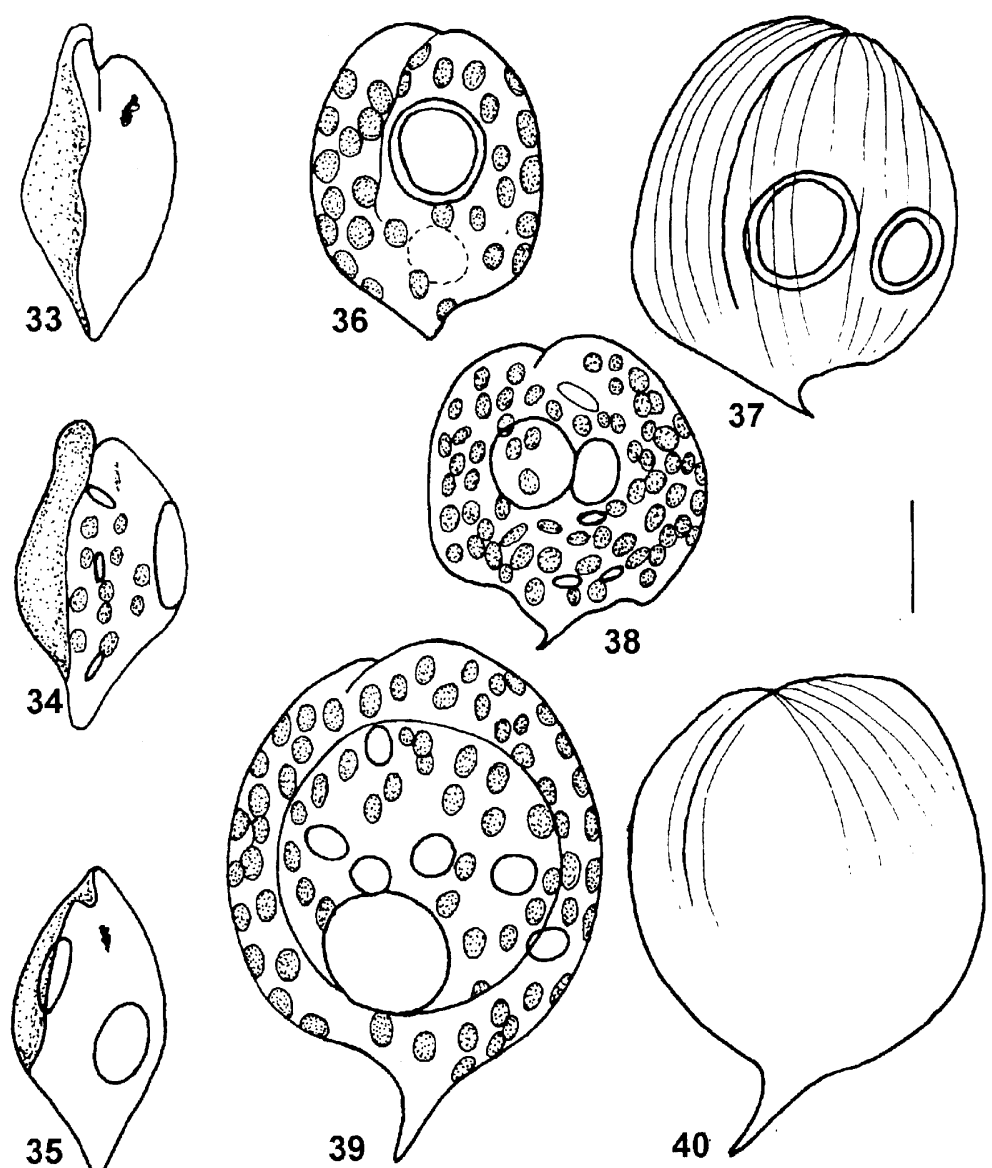

Figs 33-40. 33-35. Ph. plicatus; 36. Ph. acuminatus; 37. Ph. brachykentron; 38. Ph. curvicauda fo. robusta; 39-40. Ph. orbicularis fo. communis. Scale bar $=10 \mu \mathrm{m}$.

Cells 27-33 $\mu \mathrm{m}$ wide, 55-57 $\mu \mathrm{m}$ long, almost circular in outline or broadly oval, triangular in cross section; at the posterior end with long tail-piece ca 10-15 $\mu \mathrm{m}$ long; pellicle spirally striated, with S shaped furrow; chloroplast numerous, two large paramylon grains and numerous smaller. Rare specimens were found at the bottom of karst sink-hole (II) at Czajków.

Not common, rarely reported from Europe: Latvia, Ukraine, Asia: India and North America: Alabama.

* Phacus curvicauda Svirenko fo. robusta Allorge and Lefevre 1925. Figs 38, 69-70. Cells 27-29 um wide, 20-32 $\mu \mathrm{m}$ long, broadly oval, almost circular in outline, sometimes slightly wider than long; dorsal keel prominent and extending half length of the cell, broadly oval at the anterior end; posterior end terminating in a short curved tail-piece; pellicle longitudinally stria- ted; chloroplasts numerous and disc-shaped; paramylon bodies 2 and large; flagellum shorter than cell length. Very rare specimens were found at the bottom of karts sink-hole (II) at Czajków.

Rare, reported from Europe: Russia, occurs in ponds. Note: differs from nominal - having short apical rows and usually circular, sometimes broader than longer.

*Phacus elegans Pochmann 1942. Figs 47-49, 67. Cells 38-41 um broad, ca. $127 \mu \mathrm{m}$ long, longitudinally ob-ovoid in outline, slightly twisted; posterior end narrowing to a long, sharp tail-piece 36-41 $\mu \mathrm{m}$ long; pellicle longitudinally striated; chloroplasts small, numerous, disc-shaped; paramylon bodies small; eye-spot conspicuous; flagellum shorter than cell length. Very rare specimens were found at the bottom of sink-hole (I) at Czajków. Not common, reported 


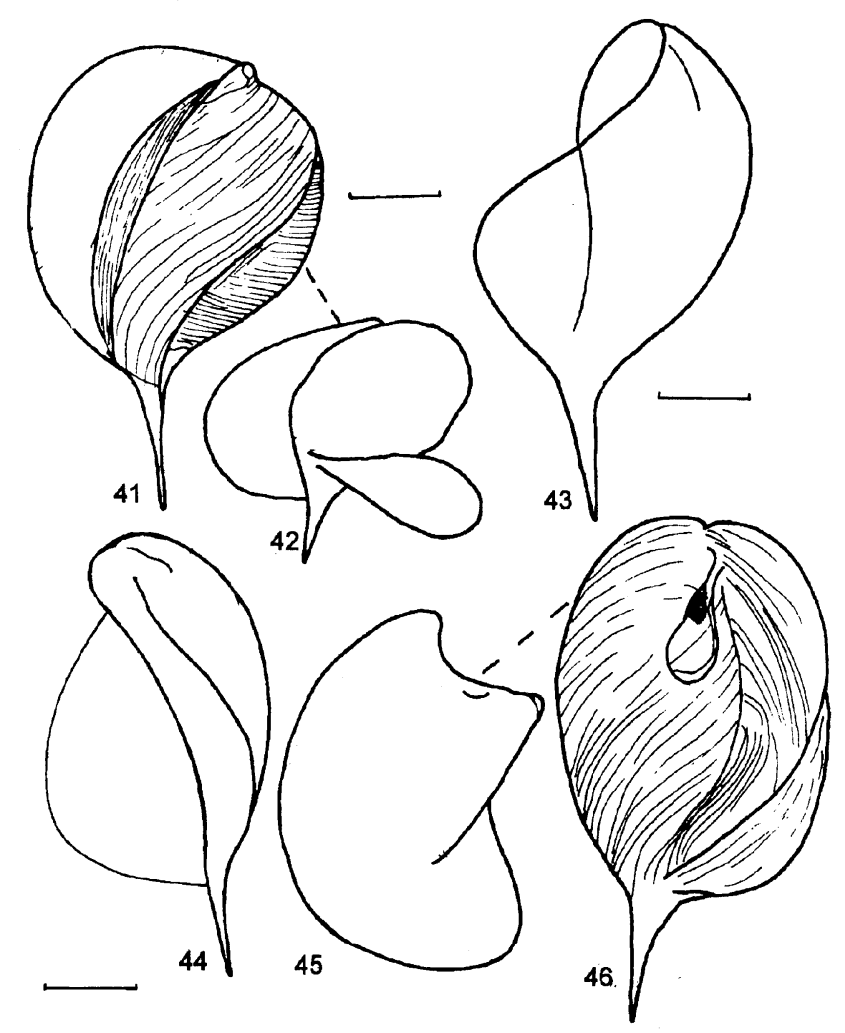

Figs 41-46. Phacus arnoldii var. ovatus, cells in different positions. Scale bar $=$ $10 \mu \mathrm{m}$.

from Europe: Germany, Czech Republic, France; North America: North Carolina; Asia: Korea, in swamps and puddles.

\section{Sectio Monomorphina Pochmann 1942}

Phacus megalopsis Pochmann 1942 (=Monomorphina megalopsis (Pochmann) Popova \& Safonova ). Figs 50-53. Cells 11.5-15.0 (m wide, 30.5-39.0 (m long, almost pyriform, spoon like curved with thin tail-piece about 12 ( $\mathrm{m}$ long; pellicle spirally ribbed; stigma large; paramylon grains small. Single specimen was found at the bottom of a sink-hole (I) at Czajkow.

Not common, reported from Europe: Czech Republic, Poland, Ukraine; North America: USA; South America: Argentina; occurs in ponds, swamps, lakes.
Note: determination of the taxa is very difficult because of several similar taxa: e.g. Phacus pyrum, Ph. mirabilis.

Phacus trypanon Pochmann 1942 (= Phacus turgidulus Pochmann). Figs 54-55. Cells ca. $18 \mu \mathrm{m}$ wide, ca. $32 \mu \mathrm{m}$ long, oval-pyriform, periplast obliquely ribbed, slightly truncated at anterior end; with long sharp extension at the posterior end, each with two large, lateral paramylon grains. Very rare specimens were found in sink-holes (I, II) at Czajków. Common, widespread, reported from Europe, Asia, Africa and South America (Wolowski 1998); occurs in various water bodies. Note: determination of the taxa is very difficult because of several similar taxa: e.g. Phacus pyrum, Ph. mirabilis, Ph. Megalopsis. Detailed studies of morpholo- 


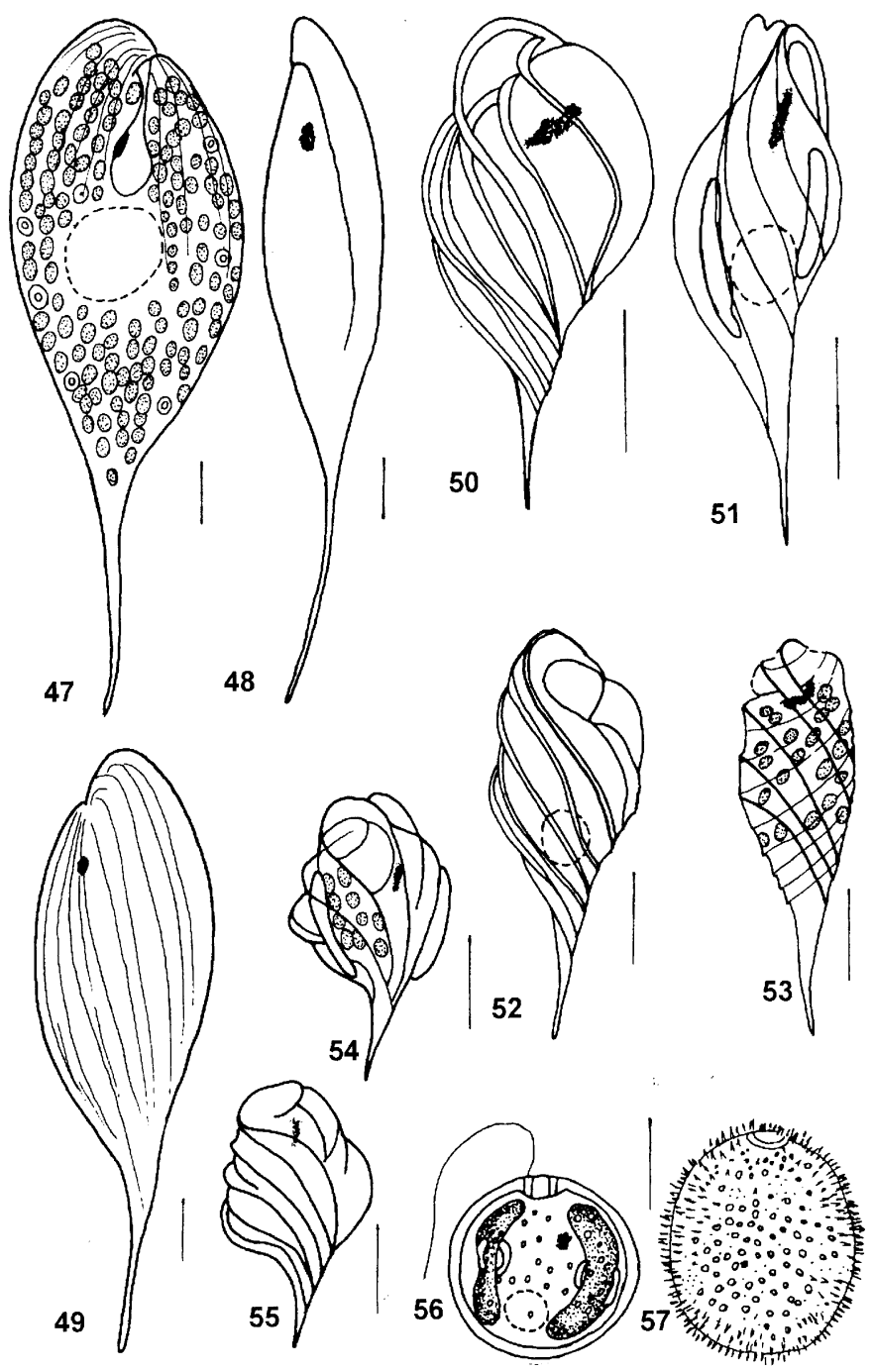

Figs 47-57. 47-49. Phacus elegans; 50-53. Ph. megalopsis; 54-55. Ph. trypanon; 56. Trachelomonas volvocina var. volvocina; 57. T. hispida. Scale bar $=10$ $\mu \mathrm{m}$.

gy and habitat conditions for Ph. trypanon were done by Kim et al. (2000).

\section{Trachelomonas Ehrenberg}

\section{Seria Volvocinae Deflandre 1926}

Trachelomonas volvocina Ehrenberg 1833 var. volvocina. Fig. 56. Lorica 6-23(-32) $\mu \mathrm{m}$ wide, spherical; walls yellowish, sometimes colourless, smooth; apical pore without a collar. Moderately numerous specimens were found in karst sink-hole (II) at Czajków. Cosmopolitan, widespread in lakes, ponds, ditches, puddles, peat bogs and wastewater; indicator of mildly to heavily polluted water.

\section{Seria Spiniferae Deflandre 1926}

Trachelomonas hispida (Perty) F. Stein emend. Deflandre 1926. Fig. 57. Lorica 15-24 $\mu \mathrm{m}$ wide, 25-27 $\mu \mathrm{m}$ long, ellipsoidal, rounded at the ends; wall uniformly and densely covered with short, sharp, conical spines, sometimes finely punctate, yellowish to reddish- 

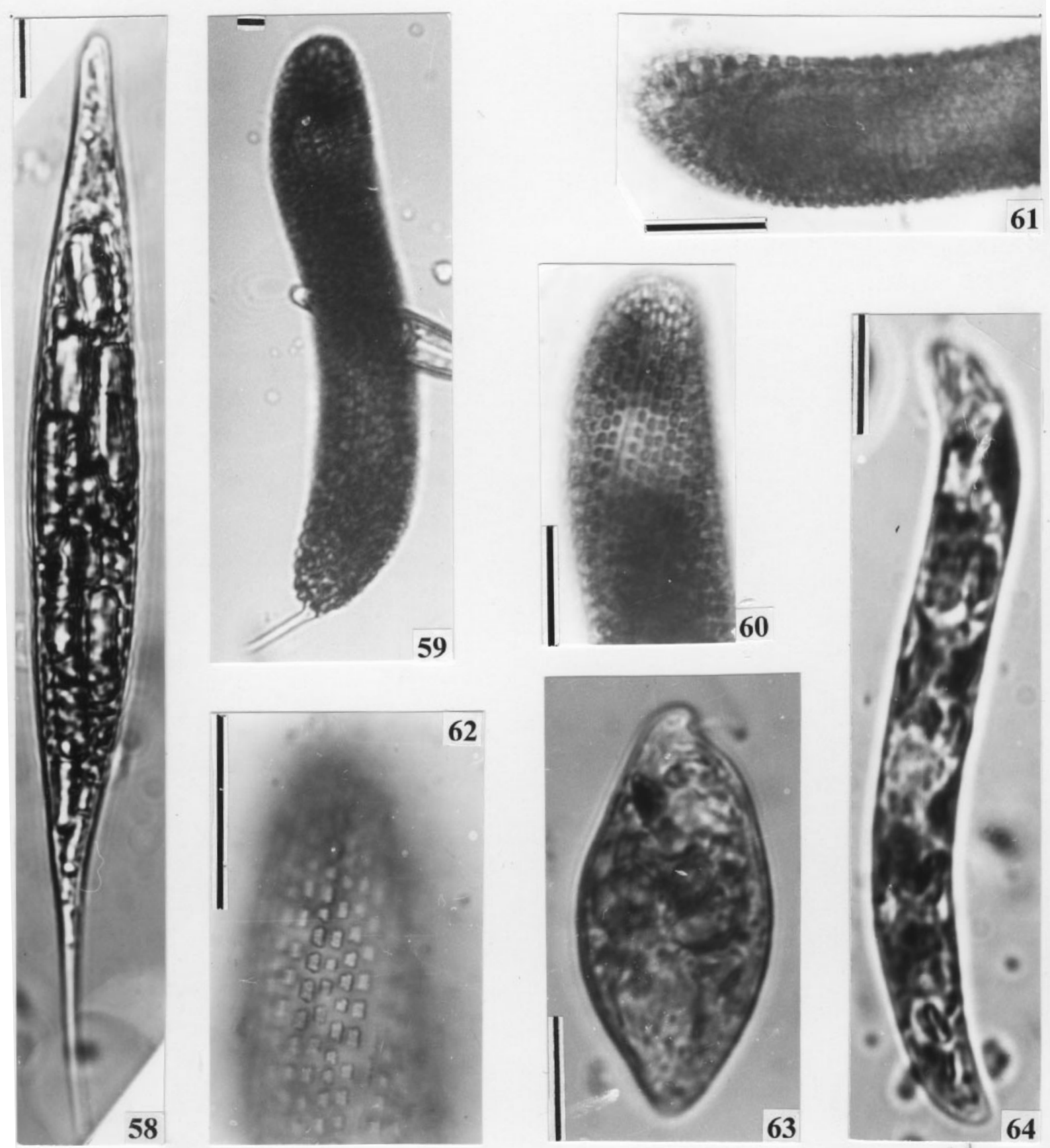

Figs 58-64. 58. E. acus; 59-62. E. spirogyra; 63. E. viridis; 64. E. deses fo. intermadia. Scale bar $=10 \mu \mathrm{m}$. 

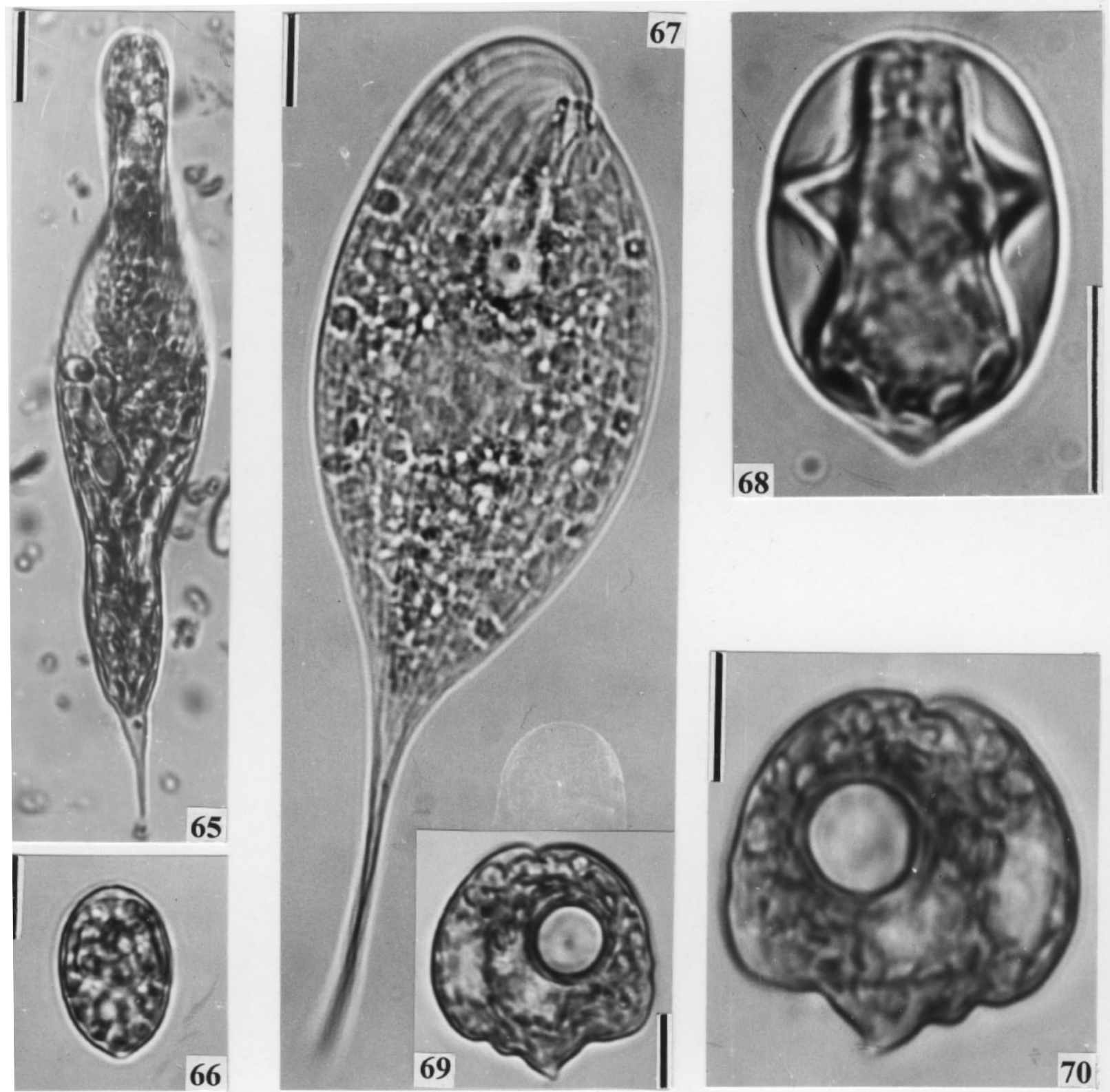

Figs. 65-70. 65. E. tripteris; 66. Lepocinclis ovum var. dimidio-minor; 67. Phacus elegans; 68. Lepocinclis ovum var. dimidio-minor; 69-70. Ph. curvicauda fo. robusta. Scale bar $=10 \mu \mathrm{m}$. 

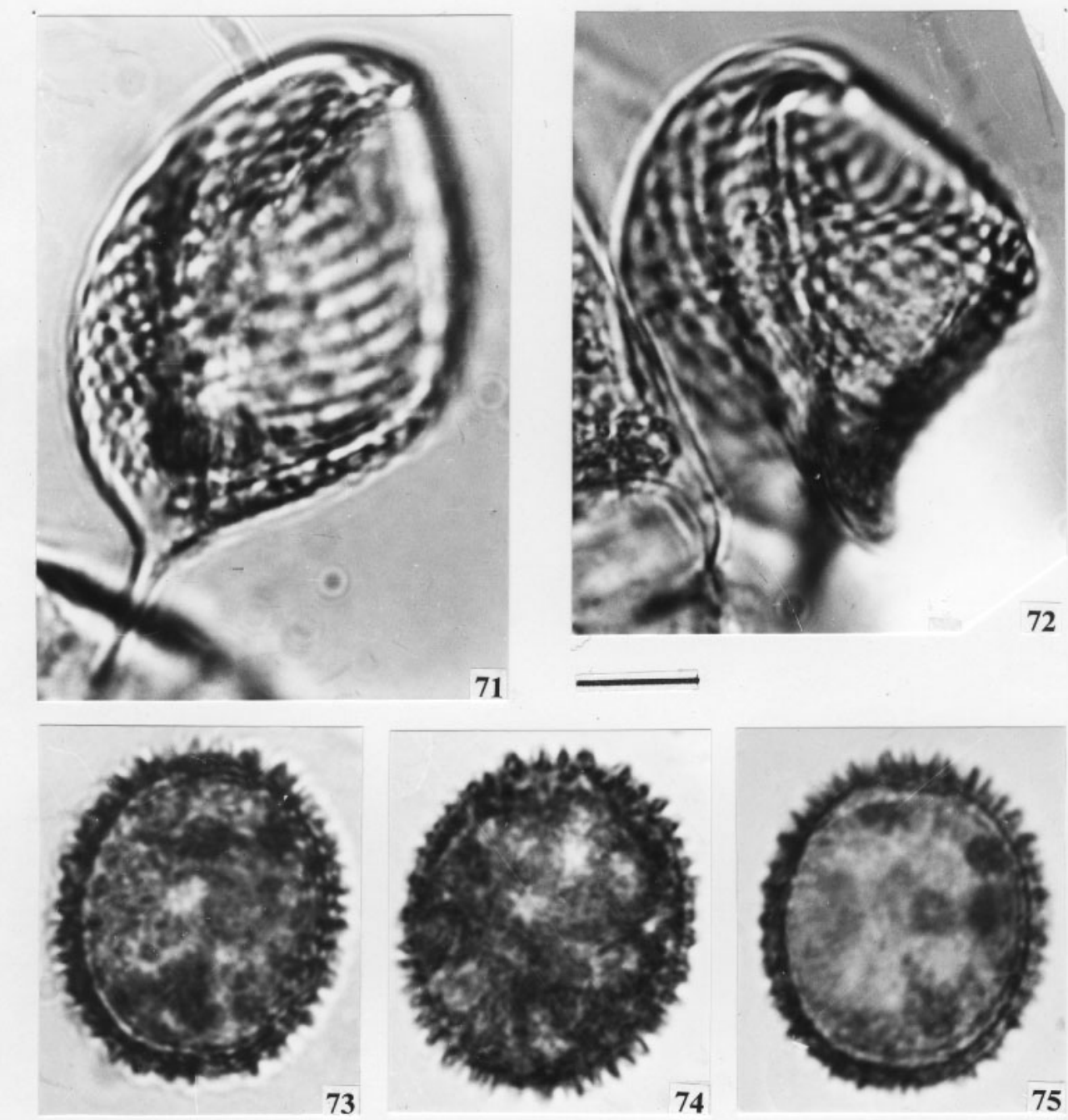

Figs 71-75. 71-72. Phacus arnoldii var. ovatus; 73-75.

brown; apical pore without a collar. Rare specimens were found in sink-hole (II) at Czajków. Cosmopolitan, widespread; occurs in swamps, ponds and ditches, in plankton hauls from stagnant water; indicator of clean to moderately polluted water.

Trachelomonas robusta Swirenko em. Deflandre 1926. Figs 73-75. Lorica ca. $23.5 \mu \mathrm{m}$ wide, ca. 27.5 $\mu \mathrm{m}$ long ellipsoidal punctate, and covered by strong conical spines, apical pore without collar, surrounded by spines. Rare specimens were found in sink-hole (II) at Czajków. Common, reported from: Europe, Africa, North and South America; occurs in swamps, ponds, puddles, oligosaprobic (Wolowski 1998). Note: similar to $T$. superba, but smaller and regularly covered by spines and to T. hispida but has stronger spines.

\section{Conclusion}

Although the investigated water bodies are situated on similar gypsum ground, a significant difference in the species composition is found. Within the studied material 24 taxa of euglenophytes were found (table 1) with the most frequent being Euglena and Phacus. Lepocinclis and Trachelomonas had only a few represen- 
tative species. No colourless euglenophytes were found. Frequency of the occurred taxa was very low in both investigated locations.

The Skorocice village fishpond was very shallow with the water surface covered by mats of Spirogyra weberii Kützig and Cladophora glomerata (L.) Kützing. Cyanopriocariota Comvophoron constrictum Anagnostidis \& Komarek, Oscillatoria terebriformis Agardh, and $O$. limosa Agardh also occurred among the mats. Several taxa of sulphuric bacteria, including Beggiatoa alba, were also abundant, forming white conglomerations while Chromatium okenii (Ehrenberg) Perty, Lamprocystis roseo-persicina (Kützing) Schroeter, Thiospira agilis (Kolkwitz) Both of them contributed to a pink-violet coloured on the surface of the mats located at the bottom of the pond. Here only representatives of the Euglena taxa (10) and Lepocinclis ovum (1) were found. Euglena viridis was the most frequent of the reported Euglena. This species was also recorded in Czajków sink-holes, where the main plant communities, consisting of Lemno-Utricularietum vulgare, Thyphetum latifoliae, Iris pseudacorus, Eriphoro-Sphagnetum, were different to those of Sko- rocice. Here, representatives of Phacus (9 taxa), Lepocinclis and two taxa of Trachelomonas mostly occurred, with the most frequent specie being Phacus orbicularis var. communis.

Most of the taxa found in both sites are cosmopolitan. Only Phacus arnoldii var. ovatus, Ph. elegans, $P$ h. plicatus, and Ph. curvicauda var. robusta are new for Polish flora and rarely reported worldwide.

This differential taxa composition in the investigated places seems to be connected with the higher water temperature and $\mathrm{pH}$. Development of the mats of $\mathrm{Spi}$ rogyra weberii and very high concentration of hydrogen sulphide make Euglena species grow better within the fish pond at Skorocice. It is very important to note that the colourless euglenophytes haven't occurred in this pond which typically contains sulphuric water. The Phacus species developed only in sink-holes due to their preference of colder water and lower $\mathrm{pH}$.

\footnotetext{
Acknowledgements

This research has been partly supported by the State Committee for Scientific Research (KBN grant 6P04C 03621). The author is grateful to Mr. Brett Leigh Dicks M.Sc. for polishing the English version of this work.
}

Table 1. Occurrence of Euglenophyceae in Skorocice fishpond and Czajków karst sink-holes. (Abundance was estimated as follows: $1=$ single, $2=$ very rare, $3=$ rare, $4=$ moderately numerous, $5=$ numerous, $6=$ very numerous). Scale bar $=10 \mu \mathrm{m}$.

\begin{tabular}{|l|c|c|c|}
\hline Taxa & Skorocice pond & \multicolumn{2}{|c|}{ Czajków sink-holes } \\
\cline { 2 - 3 } Euglena acus var. acus & & I & II \\
E. agilis & 4 & - & - \\
E. caudata & 5 & - & - \\
E. deses fo. klebsii & 4 & - & - \\
E. geniculata & 4 & - & - \\
E. limnophila var. swirencoi & 3 & - & - \\
E. proxima & 3 & - & - \\
E. spirogyra & 2 & - & - \\
E. tripteris & 3 & - & - \\
E. viridis & 3 & - & - \\
Phacus acuminatus & 6 & 3 & - \\
Ph. arnoldii var. ovatus & - & 3 & 3 \\
Ph. curvicauda var. robusta & - & - & 3 \\
Ph. elegans & - & - & 2 \\
Ph. megalopsis & - & - & 2 \\
Phacus orbicularis fo. communis & - & - & 1 \\
Ph. brachykentron & - & 3 & 3 \\
Ph. plicatus & - & 2 & 3 \\
Ph. trypanon & - & - & 2 \\
Lepocinclis ovum var. ovum & - & - & 2 \\
L. ovum var. dimidio-minor & 3 & - & - \\
Trachelomonas hiospida & 2 & - & - \\
T. robusta & - & - & 3 \\
T. volvocina & - & & 3 \\
\hline
\end{tabular}




\section{References}

Allorge P. \& Lefèvre M.1925. - Algues de Sologne. Bull. Soc. Bot France, 77, 122-150.

Conrad W. 1943. - Description de quelques Phacus nouveaux. Bull. Mus. Roy. Hist. Nat. Belg., 19, 1-8.

Conrad W. \& Van Meel L. - 1952. Matériaux pour une monographie de Trachelomonas Ehr. 1834, Strombomonas Defl. 1930 et Euglena Ehr. 1832, genres d'Euglénacees. Mem. Inst. Roy. Sci. Nat. Belg., 124,176 pp.

Carter H.J. 1856. - Notes on the freshwater Infusoria on the Island of Bombay. I. Organization. Ann. Mag. Nat. Hist., ser. 2, 18 , 115-132

Deflandre G. 1926. - Monographie du genre Trachelomonas Ehr. Andre Lesot, Nemours, 162 pp. Drezepolski R. 1925. — Supplément à la connaissance des Eugléniennes de la Pologne. Kosmos, 50, 173-270 (in Polish with French summary).

Dujardin F. 1841. - Histoire naturelle des Zoophytes-Infusoires. Paris, $684 \mathrm{pp}$.

Ehrenberg C.G. 1832. - Beitrage zur Kenntnis der Organisation der Infusorien und ihrer geographischen Verbreitung, besonders in $\mathrm{Si}$ berien. Abh. Berl. Akad. Wiss. Physik aus d. jahre 1830, Berlin, 1, $1-88$.

Ehrenberg C.G. 1833. - Dritter Beitrag zur Erkenntnis grosser Organisation in der Richtung des kleinsten Raumes. Phys. Abh. Berl. Akad. Wiss., 145-336.

Ehrenberg C.G. 1838. - Die Infusionstierchen als vollkommene Organismen. Berlin und Leipzig.

Fjerdingstad E. 1965. - Taxonomy and saprobic valency of benthic phyto-microorganisms. Int. Rev. Ges. Hydrobiol., 50, 475-604.

Hübner E. 1886. - Euglenaceenflora von Stradland. Programm d. Realgymnasiums zu Straslund. 22 pp.

Karczmarz K. \& Szczepanek K. 1976. - Sukcesje mchów na torfowiskowych obnizeniach lejków krasowych Regionu Staszowskiego. Folia Soc. Sci. Lubl. 24, Biol. 2, 135-144.

Karczmarz K., Luczycka A. \& Ochyra R. 1976. - Materialy do flory ramienic srodkowej i poludniowej Polski. 2. Acta Hydrobiol. 18, 193-200.

Kim J.T., Shin W. \& Boo S. M. 2000. - Morphology and habitat conditions of Phacus trypanon (Euglenophyceae) from Korea. Algae, 150, 17-22

Klebs G. 1883. - Über die Organisation einiger Flagellatengruppen und ihre Beziehungen zu Algen und Infusorien. Leipzig. $131 \mathrm{pp}$.

Kuc M. 1959. - Mchy Wyzyny Sandomiersko-Opatowskiej 9Okreg sandomierski). Fragm. Flor. Geobot., 5, 129-150.

Kuc M. 1964. — Biogeografia Wyzyn Poludniowych Polski. Monogr. Bot., 17, 1-212.

Leedale G.F.1967. — Euglenoid flagellates. Prentice-Hall, Inc., Englewood Cliffs, London. $243 \mathrm{pp}$

Lemmermann E. 1901. - Beiträge zur Kenntniss der Planktonalgen. Ber. Deutsch. Bot. Ges., 19, 85-95.

Lemmermann E. 1913. - Euglenineae. Süsswasserflora Deutschlands, Österreichs und der Schweiz. G. Fischer, Jena. 115-174.
Matvienko O.M. 1938. - Materyiali do vivcheniya vodorostej URSR. I. Vodorosteji Klyukvennogo bolota. Uchen. Zap. Kharkyiv. derzh. Unyiv. Kharkyiv, 14, 29-78. (in Ukrainian).

Ochyra R. 1979. - Flora lejków krasowych okolic Staszowa. I. Rosliny naczyniowe. Fragm. Flor. Geobot., 25, 209-236.

Ochyra R. 1981. - Flora lejków krasowych okolic Staszowa II. Mszaki. Fragm. Flor. Geobot., 26, 321-340.

Ochyra R. 1985. - Roslinnosc lejków krasowych w okolicach Staszowa na Wyzynie Malopolskiej - Vegetation of the karst sinkholes in the vinicity of Staszów on the Malopolska Upland. Mon. Bot., 66, 5-124.

Ochyra R. \& Szmajda P. 1978. — An annoted list of Polish mosses. Ragm. Flor. Geobot., 24, 93-145.

Pochmann A. 1942. - Synopsis der Gattung Phacus. Archiv Protistenk., 95, 81-252.

Popova T.G. 1966. - Evglenovyje vodorosli. [Euglenophyta] Flora Sporovych Rastenij SSSR, 8, Izd. Nauka, Leningrad (in Russian). $412 \mathrm{pp}$.

Popova T.G. 1947. - Sistematiceskije zametki po evglenovym. Izd. Zap. Sib. Fil. AN SSSR, Ser. Biol. 2, 47-71.

Popova T.G. 1955. — Evglenovyje vodorosli. Opredelitel presnovodnych vodoroslej SSSR. 7. Sov. Nauka. Moskva, 267 pp.

Popova T.G. \& Safonova T.A. 1976. - Flora plantarum cryptogamarum URSS, 9 (2) Euglenophyta. Izdat. "Nauka” Leningrad (in Russian), 278 pp.

Pringsheim E.G. 1956. - Contributions towards a monograph of the genus Euglena. Nova Acta Leopoldiana, 125, 3-168.

Skuja H. 1948. - Taxonomie des Phytoplanktons einiger Seen in Uppland, Schweden. Symb. Bot. Ups., 9, 183-238.

Skuja H. 1932. - Beitrag zur Algenflora Lettlands I - Materiali Latvijas algu florai. Acta Hort. Bot. Univ. Latv., 7, 25-85.

Starmach K. 1983. - Euglenophyta - Eugleniny. Flora Slodkowodna Polski, 3. PWN, Warszawa-Kraków (in Polish). 563 pp.

Swirenko D.O. 1915. - Zur Kenntnis der russischen Algenflora. 2. Euglenophyceae (excl. Trachelomonas). Arch. Hydrobiol. Planktonk, 10, 321-340.

Swirenko D.O. 1939. - Viznacnik prisnovodnich vodorostej URSR, II. Eugleninae. Izd. Akad. Nauk URSR, Kijev (in Ukrainian). $171 \mathrm{pp}$.

Szczepanek K.1968. - Kras Staszowski w swietle wyników wstepnych badan paleobotanicznych. Folia Aquatern., 29, 49-57.

Szczepanek K. 1971. - Kras staszowski w swietle badan paleobotanicznych. Acta Paleobot., 12, 61-140.

Wolowski K. 1998. - Taxonomic and environmental studies on Euglenophytes of the Kraków-Czestochowa Upland (Southern Poland). Fragm. Flor. Geobot., Suppl. 6, 192 pp.

Wolowski K. 2002. - Phylum Euglenophyta. [W]. Pages 144-179 in Freshwater flora of the British Isles. John D.M., Whitton B.A. \& A.J. Brook (eds). Cambridge University Press.

Zakrys B. 1986. - Contribution to the Monograph of Polish members of the genus Euglena Ehrenberg 1830. Nova Hedwigia, 42, 491-540. 